\title{
Pengaruh Model Pembelajaran Berbasis Masalah Berbantuan Media Lingkungan Terhadap Sikap Sosial Dan Hasil Belajar IPA Pada Siswa Kelas IV Sekolah Dasar Gugus 2 Selong Lombok Timur
}

\author{
Made Ayu Pransisca \\ Program Studi Pendidikan Guru Sekolah Dasar, Institut Pendidikan Nusantara Global, Indonesia, \\ 83511 \\ madeayupransisca@nusantaraglobal.ac.id
}

\begin{abstract}
Abstrak. Penelitian ini bertujuan untuk mengetahui pengaruh model pembelajaran berbasis masalah berbantuan media lingkungan terhadap sikap sosial dan hasil belajar IPA pada siswa kelas iv sekolah dasar gugus 2 selong lombok timur. Penelitian ini menggunakan pendekatan eksperimen semu dengan pola dasar Single Factor Independent Groups Design. Populasi dalam penelitian ini sebanyak 201 orang siswa. Sampel penelitian berjumlah 65 siswa ditentukan dengan teknik random sampling. Data sikap sosial siswa dikumpulkan dengan kuesioner, Data hasil belajar IPA siswa dikumpulkan dengan tes. Data dianalisis menggunakan MANOVA berbantuan SPSS 16.00 for windows. Hasil Penelitian menunjukkan bahwa: pertama, sikap sosial siswa yang mengikuti model pembelajaran berbasis masalah berbantuan media lingkungan secara signifikan lebih baik daripada siswa yang mengikuti model pembelajaran konvensional $(\mathrm{F}=15,847 ; \mathrm{p}<0,05)$; kedua, hasil belajar IPA siswa yang mengikuti model pembelajaran berbasis masalah berbantuan media lingkungan secara signifikan lebih baik daripada siswa yang mengikuti model pembelajaran konvensional $(\mathrm{F}=$ 39,123; p < 0,05); ketiga, secara simultan sikap sosial dan hasil belajar IPA antara siswa yang mengikuti model pembelajaran berbasis masalah berbantuan media lingkungan secara signifikan lebih baik daripada siswa yang mengikuti model pembelajaran konvensional $(\mathrm{F}=31,207$; $\mathrm{p}<0,05)$.
\end{abstract}

Kata Kunci : Hasil Belajar IPA, Model Pembelajaran Berbasis Masalah Berbantuan Media Lingkungan, Sikap Sosial,

Abstract. This study was aimed at finding out the effect of problem based learning model of media assist environment to Social Attitude and learning outcomes of science the fifth grade students of elementary school cluster 2 Selong Lombok Timur district. This study used a quasiexperiment design with Single Factor Independent Groups Design. The population consisted of 201 students. The sample was 65 students determined by random sampling technique. The data on the students Social Attitude were collected with an questionnaire. The data on the students' science learning outcomes were collected with a test. The data were analyzed using MANOVA aided with SPSS 16.00 for windows. The results showed that, First, the students' Social Attitude of those who joined the problem-based learning model of media assist environment was significantly better than that of those who joined conventional teaching model $(F=15.847 ; p<0.05)$; secondly, the students' science learning outcomes of those who joined problem-based learning model of media assist environment was significantly better than those who joined conventional teaching model $(F=39.123 ; p<0.05)$ and thirdly, simultaneously, Social Attitude and science learning outcomes of the students who joined problem based learning model of media assist environment was significantly better than that of those who joined conventional teaching model $(F=31.207 ; p<$ 0.05).

Keywords: Science Learning Outcomes, Problem Based Learning Model Of Media Assist Environment, Social Attitude. 


\section{PENDAHULUAN}

Pendidikan merupakan investasi dalam pengembangan sumber daya manusia, karena peningkatan kecakapan dan kemampuan diyakini sebagai faktor pendukung upaya manusia untuk meningkatkan kualitas hidupnya. Peran lembaga pendidikan dalam kaitannya dengan pembangunan sumber daya manusia dapat dilihat dan dirumuskan dalam konsepsi intellectual formation, yang merupakan kapasitas dari suatu bangsa untuk berpartisipasi dalam kehidupan modern yang dituntut dalam suatu masyarakat terbuka. Artinya, semakin banyak manusia terdidik, maka secara signifikan akan berdampak pula kepada kemampuan suatu bangsa dalam mengungkapkan jati dirinya dalam pergaulan global. Jika setiap warga negara telah mampu menjadikan dirinya sebagai manusia terdidik dan terlatih dalam standar internasional, maka akan semakin tampak upaya yang bisa dilakukan oleh suatu bangsa dalam meningkatkan mutu kehidupan bangsa dan negaranya. Oleh karenanya, diperlukan sistem pendidikan yang bersifat demokratis.

Pendidikan juga merupakan suatu proses dan modal dasar untuk menyiapkan sumber daya manusia yang berkualitas dan mampu membudayakan suatu masyarakat kearah sistem berpikir menurut acuan norma dan budaya tertentu yang relevan dengan tuntutan zaman. Hal tersebut sejalan dengan konsep pemikiran Dorina (2015:58) menyatakan bahwa, "Persiapan sumber daya manusia dan energi adalah kepedulian setiap manusia dan pendidikan lingkungan penting untuk menjamin gaya hidup yang berkelanjutan dalam jangka panjang". Menurut Hamalik (2001:79), "pendidikan adalah suatu proses dalam rangka mempengaruhi siswa agar dapat menyesuaikan diri sebaik mungkin terhadap lingkungannya dan dengan demikian akan menimbulkan perubahan dalam dirinya yang memungkinkannya untuk berfungsi secara adekuat dalam kehidupan masyarakat dan kemajuan bangsa". Kemajuan pendidikan suatu bangsa dapat dilihat dari pelaksanaan pendidikan di negaranya. Untuk mencapai tujuan tersebut diperlukan pendidikan dan pengajaran berbagai disiplin ilmu, kesenian, dan kemampuan/keterampilan.

Salah satu disiplin ilmu yang harus dipelajari adalah IPA. "Pendidikan IPA adalah suatu upaya untuk membelajarkan peserta didik untuk memahami hakikat IPA sebagai produk, proses, dan mengembangkan sikap sosial serta sadar akan nilai-nilai yang ada di dalam masyarakat untuk mengembangkan sikap dan tindakan berupa aplikasi IPA yang positif" (Mariana dan Praginda 2009). Bertalian dengan konsepsi Pendidikan IPA, Hacieminoglu (2016:35) menyatakan salah satu tujuan pendidikan IPA adalah "untuk mengembangkan sikap positif terhadap IPA terlepas dari perbedaan individu serta kepercayaan dan nilai yang dimiliki tentang usaha IPA di sekolah maupun dampak IPA terhadap masyarakat". Oleh sebab itu, Pendidikan IPA hendaknya ditekankan pada pemberian pengalaman langsung untuk mengembangkan kompetensi siswa agar mampu menjelajahi dan memahami pengelolaan lingkungan hidup atau alam sekitar secara ilmiah.

Dalam Undang-Undang Nomor 23 Tahun 1997 tentang Pengelolaan Lingkungan Hidup menyebutkan pengertian lingkungan adalah kesatuan ruang dengan semua benda, daya, keadaan dan makhluk hidup termasuk manusia dan prilakunya yang mempengaruhi kelangsungan perikehidupan dan kesejahteraan manusia serta makhluk hidup lain (Pasal 1 ayat 1). Lingkungan adalah keadaan sekitar yang mempengaruhi perkembangan dan tingkah laku makhluk hidup. Segala sesuatu yang ada di sekitar manusia yang mempengaruhi perkembangan kehidupan manusia baik langsung maupun tidak langsung juga merupakan pengertian lingkungan. Secara garis besar ada 2 (dua) macam lingkungan yaitu lingkungan fisik (abiotik) dan lingkungan biotik. Pertama, lingkungan fisik (abiotik) adalah segala benda mati dan keadaan fisik yang ada di sekitar individu misalnya batu-batuan, mineral, air, udara, unsur-unsur iklim, kelembaban, angin dan lain-lain. Kedua, lingkungan biotik adalah segala makhluk hidup yang ada di sekitar individu baik manusia, hewan dan tumbuhan. 
Tiap unsur biotik, berinteraksi antar biotik dan juga dengan lingkungan fisik atau lingkungan abiotik, sehingga lingkungan menjadi hidup dan menjadi satu kesatuan baik semua benda hidup dan benda mati.

$$
\text { Perkembangan IPTEK justru }
$$

memberikan peningkatan hasil kebangkrutan lingkungan. Anak-anak muda tidak mengabaikan atau kurang sensitif terhadap lingkungan" (Gunamantha, 2010:218). Hal ini tidak terlepas dari cara pembelajaran dan pengajaran yang dilakukan oleh lembaga pendidik. Salah satu upaya untuk menumbuhkan kesadaran dan sensitifitas terhadap lingkungan di kalangan anak-anak adalah dengan memanfaatkan lingkungan dalam proses pembelajaran. Peran lingkungan dan alam sekitar dalam proses pembelajaran sangatlah penting. Alam mampu memberikan kegembiraan kepada para siswa karena pada dasarnya anak usia SD taraf perkembangan intelektualnya termasuk kategori operasional konkret, dengan memanfaatkan lingkungan sekitar dalam proses pembelajaran, maka siswa dapat memperoleh pengalaman konkret sehingga diharapkan lebih mudah dalam memahami konsep pembelajaran. Sehingga lingkungan efektif digunakan sebagai media dalam pembelajaran IPA di Sekolah Dasar. Menurut Hafez (2015:13) menyatakan "bahwa salah satu tujuan yang paling penting dari proses pembelajaran IPA adalah untuk mengajarkan kepada siswa terlibat dalam penyelidikan, mengintegrasikan keterampilan, pengetahuan, dan sikap untuk mengembangkan pemahaman dan sikap sosial yang lebih baik".

Menurut Purnama (2008:115), "sikap sosial merupakan sikap yang dibentuk oleh orang yang berkecimpung dalam ilmu alamiah dan bersifat ilmiah". Sikap sosial siswa dalam proses pembelajaran IPA sangat diperlukan, terutama dalam penyelesaian masalah-masalah IPA yang memerlukan suatu pembuktian dan langkah-langkah terstruktur. Sikap sosial merupakan salah satu aspek psikis siswa yang sangat penting untuk di pupuk dan dikembangkan. Sikap sosial adalah salah satu komponen yang penting dalam pembelajaran IPA yang antara lain berupaya untuk mendidik siswa yang berilmu dan berketerampilan yang unggul serta "open minded" memiliki etos kerja yang tinggi, melatih melakukan penelitian sesuai metode ilmiah dan belajar dengan mengaplikasikan pengetahuan terbaiknya, mempunyai sikap disiplin, jujur, dan bertanggungjawab.

Kenyataan yang ada di lapangan menunjukkan bahwa, Sikap sosial yang dimiliki oleh siswa belum berkembang secara optimal, hal tersebut didukung oleh hasil studi Kementerian Lingkungan Hidup (KLH) Indonesia tahun 2014 (Administrator, 2013) menunjukkan bahwa Indeks Perilaku Peduli Lingkungan (IPPL) dan sikap sosial masih berkisar pada angka 0,57 (dari angka mutlak 1). Hal ini mengindikasikan bahwa masyarakat Indonesia belum sepenuhnya berperilaku peduli lingkungan dalam menjalankan kehidupan sehari-hari serta belum optimalnya atau masih rendahnya pengembangan sikap sosial siswa. Selain itu, peneliti juga melakukan observasi dan wawancara dengan wali kelas IV di masingmasing Sekolah Dasar Gugus 2 mengenai rendahnya sikap sosial dan hasil belajar IPA. Berdasarkan data hasil observasi dan wawancara yang peneliti lakukan, dapat diidentifikasi bahwa terdapat beberapa gejala/faktor yang menyebabkan rendahnya sikap sosial dan hasil belajar IPA siswa, yaitu (1) proses pembelajaran yang dilakukan masih berpusat pada guru dengan didominasi metode ceramah dan tanya jawab. (2) masih rendahnya sikap sosial siswa terutama dalam hal memberikan ide-ide/pendapat, sikap optimis, kreatifitas, rasa ingin tahu dan keaktifan siswa yang masih kurang dalam proses pembelajaran; (3) saat diberikan suatu permasalahan yang nyata (konkret), siswa belum bisa memadukan dengan pembelajaran teoritis; (4) siswa masih kurang dalam menyimpulkan materi dengan menggunakan kata-kata sendiri; (5) siswa mudah mengantuk dan kehilangan konsentrasi sehingga daya bersaing untuk unggul belum terlihat; (6) kurangnya kemampuan guru dalam mengembangkan bahan ajar/media dalam proses pembelajaran. Berdasarkan paparan di 
atas membuktikan bahwa masih rendahnya sikap sosial dan hasil belajar IPA siswa.

Menyadari adanya permasalahan yang ditemukan di masing-masing Sekolah Dasar Gugus 2 maka salah satu upaya/solusi yang dapat ditawarkan untuk meningkatkan sikap sosial dan hasil belajar IPA siswa adalah dengan menerapkan kegiatan dan bahan pembelajaran yang dapat menciptakan pembelajaran yang efektif. Pembelajaran tidak hanya fokus pada pemberian kemampuan pengetahuan teoritis, tetapi bagaimana agar pengalaman belajar peserta didik senantiasa terkait dengan permasalahan aktual yang terjadi di lingkungannya (Rusman, 2011). Kegiatan dan bahan pembelajaran harus sesuai dengan lingkungan peserta didik serta terkait pengalamannya dari interaksi dengan lingkungan, sehingga pembelajaran harus berisi bahan dan kegiatan pembelajaran yang memungkinkan peserta didik belajar untukmengeksplorasi lingkungannya secara aktif. Media pembelajaran yang berbantuan pada lingkungan dapat diterapkan dalam pembelajaran IPA. Pembelajaran yang dapat memungkinkan siswa untuk membentuk konsep berdasarkan permasalahan kehidupan nyata yang dipecahkan sendiri adalah pembelajaran berbasis masalah. Pembelajaran berbasis masalah dapat membuat siswa belajar melalui upaya penyelesaian permasalahan dunia nyata secara terstruktur untuk mengonstruksikan pengetahuan siswa. Hal senada juga disampaikan Wikut (2017:5) menyatakan bahwa, "Problem Based Learning merupakan suatu metode atau cara pembelajaran yang ditandai oleh adanya masalah nyata (a real world problem) sebagai sebuah konteks bagi para pembelajar untuk belajar berpikir kritis dan keterampilan memecahkan masalah serta memperoleh pengetahuan". Pembelajaran berbasis masalah berlandaskan pada teori konstruktivistik,yangmengakomodasi

keterlibatan peserta didik dalam belajar dan pemecahan masalah otentik (Marhaeni, 2013:137).

Pembelajaran berbasis masalah
membantu untuk menunjukkan dan

memperjelas cara berpikir serta kekayaan dari struktur dan proses kognitif yang terlibat di dalamnya. "Pembelajaran berbasis masalah mengoptimalkan tujuan, kebutuhan, motivasi, hasil belajar yang mengarahkan suatu proses belajar yang merancang berbagai macam kognisi pemecahan masalah dikaitkan dengan lingkungan kontekstual siswa" (Rusman, 2012: 232). Beranjak dari paradigma tersebut, dilaksanakan sebuah penelitian dengan menggunakan model pembelajaran berbasis masalah berbantuan media lingkungan, maka peneliti memasukkan ide ini ke dalam penelitian yang berjudul "Pengaruh Model Pembelajaran Berbasis Masalah Berbantuan Media Lingkungan Terhadap Sikap sosial Dan Hasil Belajar IPA Pada Siswa kelas iv sekolah dasar gugus 2 selong lombok timur".

Mengingat masalah tersebut sangat penting, maka dilakukan penelitian dengan tujuan: 1) Untuk menganalisis dan mendeskripsikan perbedaan sikap sosial antara siswa yang mengikuti model pembelajaran berbasis masalah berbantuan media lingkungan dengan model pembelajaran konvensional pada siswa kelas iv sekolah dasar gugus 2 selong lombok timur, 2) Untuk menganalisis dan mendeskripsikan perbedaan hasil belajar IPA antara siswa yang mengikuti model pembelajaran berbasis masalah berbantuan media lingkungan dengan model pembelajaran konvensional pada siswa kelas iv sekolah dasar gugus 2 selong lombok timur, dan 3) Untuk menganalisis dan mendeskripsikan perbedaan sikap sosial dan hasil belajar IPA secara simultan antara siswa yang mengikuti model pembelajaran berbasis masalah berbantuan media lingkungan dengan model pembelajaran konvensional pada siswa kelas iv sekolah dasar gugus 2 selong lombok timur.

\section{METODE PENELITIAN}

Penelitian ini dilaksanakan di Gugus 2 Tahun Pelajaran 2017/2018. Jenis penelitian ini dikategorikan penelitian eksperimen semu (quasy exsperiment). Desain penelitian adalah single factor independent group design dengan menggunakan kelompok eksperimen 
(model pembelajaran berbasis masalah berbantuan media lingkungan) dan kelompok kontrol (model pembelajaran konvesional). Populasi dalam penelitian ini adalah seluruh siswa kelas IV Gugus 2 Selong Lombok Timur.Teknik pengambilan sampel dengan random sampling. Hasil pemilihan sampel menetapkan kelas IV SD N 2 Selong dengan siswa sejumlah 32 orang sebagai kelompok eksperimen yang menerapkan model pembelajaran berbasis masalah berbantuan media lingkungan dan kelas IV SD $\mathrm{N} 8$ Selong dengan siswa sebanyak 33 orang sebagai kelompok kontrol yang menerapkan model pembelajaran konvensional. Variabel bebas dalam penelitian ini berupa model pembelajaran berbasis masalah berbantuan media lingkungan dan model pembelajaran konvensional sedangkan variabel terikatnya berupa sikap sosial dan hasil belajar IPA. Teknik pengumpulan data yang digunakan dalam penelitian ini adalah teknik tes dan non-tes. Teknik tes digunakan untuk mengambil data hasil belajar IPA, dalam penelitian ini tes yang digunakan adalah tes objektif dengan bentuk pilihan ganda dan Teknik non-tes dalam penelitian ini dengan menggunakan lembar kuesioner sikap sosial siswa dengan modifikasi dari skala Likert. Analisis data yang digunakan pada penelitian ini analisis statistik deskriptif, yang artinya bahwa data dianalisis dengan menghitung nilai rata-rata, modus, median, standar deviasi, varian, skor maksimum, dan skor minimum. Dalam penelitian ini data disajikan dalam bentuk grafik histogram. Teknik yang digunakan untuk menganalisis data guna menguji hipotesis penelitian adalah MANOVA. Sebelum dilakukan analisis data, maka dilakukan uji normalitas sebaran data dengan menggunakan uji Kolmogorovsmirnov, uji homogenitas varians dengan uji Levene's, dan uji korelasi antar variabel terikat (kolinieritas) dengan menggunakan product moment.

\section{Hasil Analisis Data}

Adapun hasil analisis data statistik deskriptif disajikan pada tabel 4.3

Tabel 4.3:Rekapitulasi Hasil Perhitungan tentang Sikap sosial dan Hasil Belajar IPA

Kelompok Siswa yang Mengikuti Model

Pembelajaran Berbasis Masalah Berbantuan

Media Lingkungan dan Kelompok yang Mengikuti Model Pembelajaran Konvensional

\begin{tabular}{|c|c|c|c|c|}
\hline Statistik $\quad$ Variabel & $\mathrm{A}_{1} \mathrm{Y}_{1}$ & $\mathrm{~A}_{1} \mathrm{Y}_{2}$ & $\mathrm{~A}_{2} \mathrm{Y}_{1}$ & $\mathrm{~A}_{2} \mathrm{Y}_{2}$ \\
\hline $\mathrm{N}$ & 32 & 32 & 33 & 33 \\
\hline Mean & 148,06 & 26,18 & 138,45 & 19,15 \\
\hline Median & 149,00 & 26,00 & 136,00 & 20,00 \\
\hline Modus & 145 & 28 & 133 & 22 \\
\hline Standar Deviasi & 9,094 & 3,788 & 10,305 & 5,154 \\
\hline Varians & 82,706 & 14,351 & 106,193 & 26,570 \\
\hline Range & 40 & 14 & 40 & 17 \\
\hline Skor minimum & 130 & 18 & 121 & 11 \\
\hline Skor maximum & 170 & 32 & 161 & 28 \\
\hline
\end{tabular}

Data sikap sosial siswa yang mengikuti pembelajaran dengan model pembelajaran berbasis masalah berbantuan media lingkungan $\left(\mathrm{A}_{1} \mathrm{Y}_{1}\right)$ menunjukkan skor minimal 130, skor maksimal 170, rentangan 40, rata-rata (mean) sebesar 148,06, standar deviasi sebesar 9,094, modus sebesar 145, dan median sebesar 149,00. Untuk mendapatkan gambaran yang lebih jelas, sikap sosial siswa yang mengikuti model pembelajaran berbasis masalah berbantuan media lingkungan dapat digambarkan pada grafik histogram berikut.

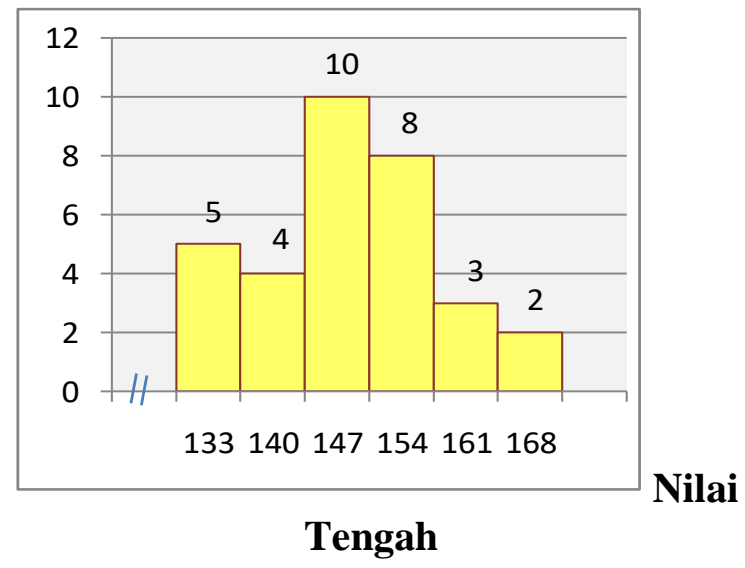

Gambar 4.4: Histogram Distribusi Frekuensi Sikap sosial Siswa yang Mengikuti Model Pembelajaran Berbasis Masalah Berbantuan Media Lingkungan.

Berdasarkan pada hasil perhitungan di atas, dapat disimpulkan bahwa Sikap sosial Siswa Yang Mengikuti Model Pembelajaran Berbasis Masalah Berbantuan Media Lingkungan termasuk pada kategori "tinggi". 
Data hasil belajar IPA siswa yang mengikuti model pembelajaran berbasis masalah berbantuan media lingkungan $\left(\mathrm{A}_{1} \mathrm{Y}_{2}\right)$ menunjukkan skor minimal 18, skor maksimal 32, rentangan 14, rata-rata (mean) sebesar 26,18, standar deviasi sebesar 3,788, modus sebesar 28, dan median sebesar 26,00. Untuk mendapatkan gambaran yang lebih jelas, hasil belajar IPA siswa yang mengikuti model pembelajaran berbasis masalah berbantuan media lingkungan dapat digambarkan pada grafik histogram berikut.

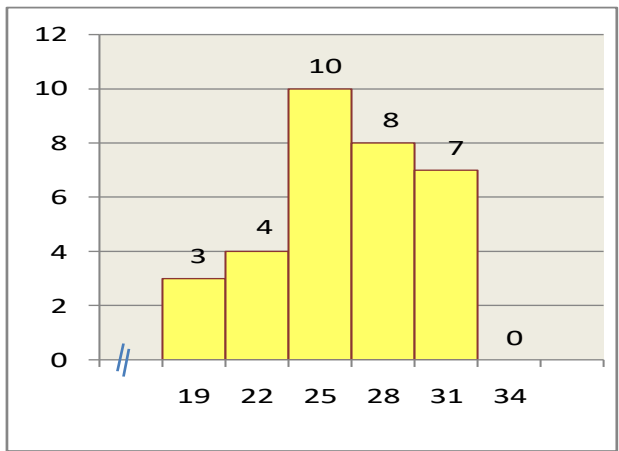

Nilai Tengah

Gambar 4.5: Histogram Distribusi Frekuensi Hasil Belajar IPA Siswa yang Mengikuti Model Pembelajaran Berbasis Masalah Berbantuan Media Lingkungan.

Berdasarkan pada hasil perhitungan di atas, dapat disimpulkan bahwa Hasil Belajar IPA Siswa Yang Mengikuti Model Pembelajaran Berbasis Masalah Berbantuan Media Lingkungan termasuk pada kategori "tinggi".

Data sikap sosial siswa yang mengikuti model pembelajaran konvensional $\left(\mathrm{A}_{2} \mathrm{Y}_{1}\right)$ menunjukkan skor minimal 121, skor maksimal 161, rentangan 40, rata-rata (mean) sebesar 138,45, standar deviasi sebesar 10,305 , modus sebesar 133, dan median sebesar 136,00. Untuk mendapatkan gambaran yang lebih jelas, sikap sosial siswa yang mengikuti model pembelajaran konvensional dapat digambarkan pada grafik histogram berikut.

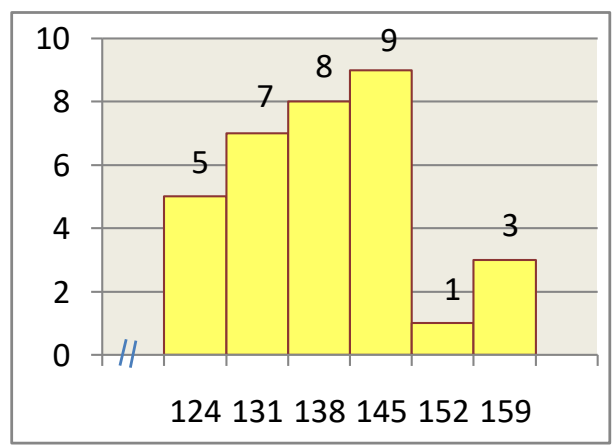

Nilai Tengah

Gambar 4.6: Histogram Distribusi Frekuensi Sikap sosial Siswa yang Mengikuti Model Pembelajaran Konvensional.

Berdasarkan pada hasil perhitungan di atas, dapat disimpulkan bahwa Sikap sosial Siswa Yang Mengikuti Model Pembelajaran Konvensional termasuk pada kategori "tinggi".

Data hasil belajar IPA siswa yang mengikuti model pembelajaran konvensional $\left(\mathrm{A}_{2} \mathrm{Y}_{2}\right)$ menunjukkan skor minimal 11, skor maksimal 28, rentangan 17, rata-rata (mean) sebesar 19,15, standar deviasi sebesar 5,154, modus sebesar 22, dan median sebesar 20,00. Untuk mendapatkan gambaran yang lebih jelas, hasil belajar IPA siswa yang mengikuti model pembelajaran konvensional dapat digambarkan pada grafik histogram berikut.

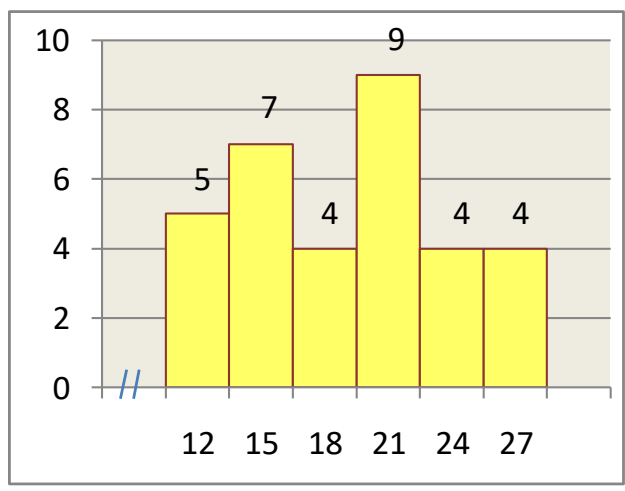

Nilai Tengah

Gambar 4.7: Histogram Distribusi Frekuensi Hasil Belajar IPA Siswa yang Mengikuti Model Pembelajaran Konvensional.

Berdasarkan pada hasil perhitungan di atas, dapat disimpulkan bahwa Hasil Belajar IPA Siswa Yang Mengikuti Model Pembelajaran Konvensional termasuk pada kategori "sedang".

$\begin{array}{cccc}\text { Siswa } & \begin{array}{c}\text { Perbedaan } \\ \text { yang }\end{array} & \begin{array}{c}\text { Sikap sosial } \\ \text { Mengikuti }\end{array} & \begin{array}{c}\text { antara } \\ \text { Model }\end{array}\end{array}$ 


\section{Pembelajaran Berbasis Masalah Berbantuan Media Lingkungan dengan Siswa yang Mengikuti Model Pembelajaran Konvensional}

Berdasarkan hasil temuan dalam penelitian ini, memiliki nilai $F$ sebesar 15,847 dengan nilai signifikansi 0,000 atau lebih kecil dari 0,05 . Itu berarti pula bahwa hipotesis nol yang menyatakan tidak terdapat perbedaan sikap sosial siswa yang mengikuti model pembelajaran berbasis masalah berbantuan media lingkungan dengan siswa yang mengikuti model pembelajaran konvensional, "ditolak". Dengan demikian dapat ditarik kesimpulan bahwa terdapat perbedaan sikap sosial siswa yang mengikuti model pembelajaran berbasis masalah berbantuan media lingkungan dengan siswa yang mengikuti model pembelajaran konvensional.

Penelitian lain yang mendukung temuan ini adalah Ayu Surya (2016) yang menyatakan bahwa terdapat perbedaan sikap sosial dalam pembelajaran IPA secara signifikan antara siswa yang belajar dengan menggunakan model pembelajaran berbasis masalah dan model pembelajaran konvensional.

Penelitian lainnya yang mendukung temuan ini adalah Wikut Deniarti (2017) yang menyatakan bahwa terdapat perbedaan sikap sosial dalam pembelajaran IPA secara signifikan antara siswa yang belajar dengan menggunakan model pembelajaran berbasis masalah dan model pembelajaran konvensional.

Temuan penelitian lainnya yang sejalan dengan penelitian ini didukung oleh penelitian Melek Demiral \& Miray Dagyar (2016) yang menyatakan bahwa, terdapat perbedaan sikap sosial siswa dalam pembelajaran IPA secara signifikan antara siswa yang belajar dengan menggunakan model pembelajaran berbasis masalah dan model pembelajaran konvensional.

Penelitian lainnya yang juga mendukung temuan ini adalah Dyan Wulan Sari (2017) yang menyatakan bahwa terdapat perbedaan keterampilan proses dan sikap sosial dalam pembelajaran IPA secara signifikan antara siswa yang belajar dengan menggunakan model pembelajaran berbasis masalah dan model pembelajaran konvensional.

Model pembelajaran berbasis masalah adalah suatu model pembelajaran yang menuntut peserta didik untuk berpikir kritis, memecahkan masalah, belajar secara mandiri, dan menuntut keterampilan berpatisipasi dalam tim. Proses pemecahan masalah dilakukan secara kolaborasi dan disesuaikan dengan kehidupan. Pembelajaran berbasis masalah digunakan untuk merangsang berpikir tingkat tinggi dalam situasi berbantuan masalah termasuk di dalamnya bagaimana tentang belajar.

Penerapan model pembelajaran berbasis masalah dimulai dengan masalah secara individual maupun kelompok. Masalah yang dihadapkan yaitu masalah yang konseptual untuk dicari pemecahannya. Masalah berasal dari dunia nyata yang berhubungan dengan kehidupan siswa seharihari yang tidak asing bagi kehidupan siswa bersangkutan. Organisasi materi pembelajaran disesuaikan dengan masalah, guru memediasi dan memfasilitasi pembelajaran. Siswa terbentuk dalam kelompok-kelompok, siswa diberikan tanggung jawab untuk mengarahkan pembelajaran, serta siswa mempresentasikan hasil diskusi kelompoknya.

Pembelajaran berbasis masalah menyajikan kepada siswa situasi masalah yang autentik dan bermakna, masalah yang dapat diambil yakni masalah yang berkaitan dengan lingkungan yang akan dijadikan sebagai media atau bahan ajar pembelajaran. Sehinga sesuai dengan sintak model pembelajaran berbasis masalah tersebut sangat cocok dengan sikap sosial. Dalam sikap sosial suatu kegiatan yang berhubung dengan konsep yang diberikan atau masalah yang dipaparkan yang secara tidak langsung meningkatkan kemampuan sikap sosial siswa seperti: sikap jujur, terbuka, toleran, skeptis, optimis, pemberani, kreatif, dan peduli lingkungan. Hal ini didukung oleh data yang dikumpulkan melalui kuesioner dalam penelitian ini.

Berdasarkan hasil penelitian di atas, dapat disimpulkan bahwa model 
pembelajaran berbasis masalah berbantuan media lingkungan sangat efektif diterapkan untuk meningkatkan sikap sosial siswa.

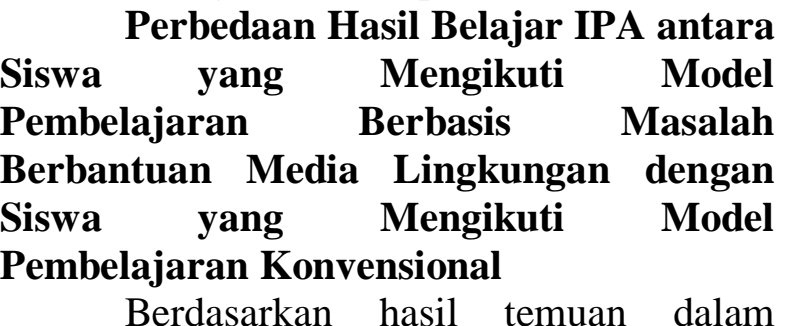
penelitian ini, memiliki nilai $\mathrm{F}$ sebesar 39,123 dengan nilai signifikansi 0,000 atau lebih kecil dari 0,05. Itu berarti pula bahwa hipotesis nol yang menyatakan tidak terdapat perbedaan hasil belajar IPA siswa yang mengikuti model pembelajaran berbasis masalah berbantuan media lingkungan dengan siswa yang mengikuti model pembelajaran konvensional, "ditolak". Dengan demikian dapat ditarik kesimpulan bahwa terdapat perbedaan hasil belajar IPA siswa yang mengikuti model pembelajaran berbasis masalah berbantuan media lingkungan dengan siswa yang mengikuti model pembelajaran konvensional.

Temuan penelitian ini sejalan didukung oleh penelitian Wijaya (2015) yang menyatakan bahwa, terdapat perbedaan hasil belajar dalam pembelajaran IPA secara signifikan antara siswa yang belajar dengan menggunakan model pembelajaran berbasis masalah dan model pembelajaran konvensional.

Penelitian lain yang mendukung temuan ini adalah Ayu Surya (2016) yang menyatakan bahwa terdapat perbedaan hasil belajar dalam pembelajaran IPA secara signifikan antara siswa yang belajar dengan menggunakan model pembelajaran berbasis masalah dan model pembelajaran konvensional.

Penelitian lain yang juga mendukung temuan ini adalah Ratelit Tarigan (2017) yang menyatakan bahwa terdapat perbedaan hasil belajar dalam pembelajaran IPA secara signifikan antara siswa yang belajar dengan menggunakan model pembelajaran berbasis masalah dan model pembelajaran konvensional.
Penelitian lain yang juga mendukung temuan ini adalah Zulkarnaen (2017) yang menyatakan bahwa terdapat perbedaan hasil belajar dalam pembelajaran IPA secara signifikan antara siswa yang belajar dengan menggunakan model pembelajaran berbasis masalah dan model pembelajaran konvensional.

Dalam peningkatan hasil belajar IPA, tentu berbagai usaha guru dilakukan, seperti penggunaan berbagai model pembelajaran inovatif yang dimaksudkan untuk mengaktifkan belajar serta meningkatkan hasil belajar siswa. Dalam hal ini penggunaan model pembelajaran berbasis masalah dalam pembelajaran IPA siswa, dipandang sesuai karena model pembelajaran berbasis masalah dimulai dengan penyampaian masalah kepada siswa, yang tentu saja masalah tersebut sesuai dengan tingkat kemampuan siswa, serta permasalahan yang terjadi sesuai dengan kehidupan sehari-hari siswa dengan kata lain masalah yang autentik yang ada di sekitar lingkungan siswa. Dan akhirnya dipecahkan sendiri oleh siswa pula. Diharapkan siswa mendapatkan konsep-konsep sesuai tujuan pembelajaran.

Model pembelajaran berbasis masalah berbantuan media lingkungan merupakan model pembelajaran yang mampu menggiatkaan peserta didik untuk berpikir secara aktif, kreatif, dan bekerja atas inisiatifnya sendiri, untuk merumuskan hipotesis terhadap masalah yang dihadapi dengan mengaitkannya dalam kehidupan sehari-hari. Model pembelajaran berbasis masalah berbantuan media lingkungan lebih mengutamakan peserta didik untuk mengkonstruksi pengetahuan pada dirinya, mendorong peserta didik menemukan pengetahuan melalui interaksi dengan lingkungannya.

Berdasarkan hasil penelitian di atas, dapat disimpulkan bahwa model pembelajaran berbasis masalah berbantuan media lingkungan sangat efektif diterapkan untuk meningkatkan hasil belajar dalam pembelajaran IPA siswa. 
Perbedaan Sikap sosial dan Hasil Belajar IPA antara Siswa yang Mengikuti Model Pembelajaran Berbasis Masalah Berbantuan Media Lingkungan dengan Siswa yang Mengikuti Model Pembelajaran Konvensional

Berdasarkan hasil temuan dalam penelitian ini, yang menunjukkan bahwa harga F untuk Pillai's Trace, Wilks' Lambda, Hotelling's Trace, dan Roy's Largest Root memiliki nilai signifikansi lebih kecil daripada 0,05 . Dengan rata-rata skor sikap sosial siswa yang mengikuti pembelajaran dengan model pembelajaran berbasis masalah berbantuan media lingkungan adalah 148,06 lebih besar daripada skor rata-rata siswa yang mengikuti model pembelajaran konvensional yaitu sebesar 138,45, dan rata-rata skor hasil belajar IPA siswa yang mengikuti model pembelajaran berbasis masalah berbantuan media lingkungan adalah 26,18 lebih besar daripada siswa yang mengikuti model pembelajaran konvensional yaitu sebesar 19,15. Jadi hipotesis nol yang berbunyi tidak terdapat perbedaan Sikap sosial dan hasil belajar IPA secara simultan antara siswa yang mengikuti pembelajaran berbasis masalah berbantuan media lingkungan dengan siswa yang mengikuti model pembelajaran konvensional, "ditolak" dan hipotesis alternatif "diterima". Dengan demikian, terdapat perbedaan Sikap sosial dan hasil belajar IPA secara simultan antara siswa yang mengikuti pembelajaran berbasis masalah berbantuan media lingkungan dengan siswa yang mengikuti model pembelajaran konvensional.

Temuan penelitian ini sejalan didukung oleh penelitian Wijaya (2015) yang menyatakan bahwa, terdapat perbedaan sikap sosial dan hasil belajar dalam pembelajaran IPA secara signifikan antara siswa yang belajar dengan menggunakan model pembelajaran berbasis masalah dan model pembelajaran konvensional.

Penelitian lain yang mendukung temuan ini adalah Ayu Surya (2016) yang menyatakan bahwa terdapat perbedaan sikap sosial dan hasil belajar dalam pembelajaran IPA secara signifikan antara siswa yang belajar dengan menggunakan model pembelajaran berbasis masalah dan model pembelajaran konvensional.

Temuan penelitian lain yang sejalan dengan penelitian ini didukung oleh penelitian Sunariyati (2014) yang menyatakan bahwa, terdapat perbedaan sikap sosial dan hasil belajar dalam pembelajaran IPA secara signifikan antara siswa yang belajar dengan menggunakan model pembelajaran berbasis masalah dan model pembelajaran konvensional.

Model pembelajaran berbasis masalah berbantuan media lingkungan merupakan model pembelajaran yang mampu menggiatkaan peserta didik untuk berpikir secara aktif, kreatif, dan bekerja atas inisiatifnya sendiri, untuk merumuskan hipotesis terhadap masalah yang dihadapi dengan mengaitkannya dalam kehidupan sehari-hari. Model pembelajaran berbasis masalah berbantuan media lingkungan lebih mengutamakan peserta didik untuk mengkonstruksi pengetahuan pada dirinya, mendorong peserta didik menemukan pengetahuan melalui interaksi dengan lingkungannya.

Hasil ini sekaligus menunjukkan bahwa sikap sosial dan hasil belajar IPA Siswa yang mengikuti pembelajaran dengan model pembelajaran berbasis masalah berbantuan media lingkungan lebih baik dari kelompok siswa yang mengikuti pembelajaran dengan model pembelajaran konvensional.

\section{PENUTUP}

Berdasarkan temuan di atas, dapat disimpulkan bahwa model pembelajaran berbasis masalah berbantuan media lingkungan memberikan pengaruh yang signifikan terhadap sikap sosial dan hasil belajar IPA pada siswa kelas IV Sekolah Dasar di Gugus 2 Selong Lombok Timur.

Berdasarkan temuan-temuan dan simpulan yang telah dikemukakan di atas, adapun saran yang dapat diajukan dalam penelitian ini adalah sebagai berikut. Bagi Siswa, Siswa hendaknya mampu mengemukakan permasalahan - permasalahan 
ataupun kendala-kendala yang dihadapinya dalam proses pembelajaran. Hal ini bertujuan agar permasalahan-permasalahan ataupun kendala-kendala yang dihadapi oleh siswa dapat diberikan solusi yang optimal oleh guru. Bagi Guru, Guru hendaknya mampu memahami dan mengerti kendala-kendala yang dihadapi oleh siswa dalam proses pembelajaran, sehingga guru dapat memberikan solusi yang tepat untuk mengatasi kendala tersebut. Guru hendaknya selalu menggunakan model-model yang inovatif dalam proses pembelajaran dan melakukannya secara kontinue/berkelanjutan, supaya siswa tidak jenuh dan menjadi senang dalam mengikuti proses pembelajaran. Selain itu, guru juga harus kreatif, cerdas, dan berinovasi dalam membuat soal permasalahan yang realistik guna siswa lebih mudah mengerti. Bagi Kepala Sekolah, Kepala sekolah hendaknya selalu memberikan dukungan terhadap inovasi-inovasi yang dilakukan oleh guru dalam proses pembelajaran. Selain itu kebijakan yang dikeluarkan oleh kepala sekolah hendaknya memberikan dampak yang positif terhadap peningkatan kemampuan guru maupun siswa. Bagi Peneliti Lain, Model pembelajaran berbasis masalah berbantuan media lingkungan memberikan pengaruh yang signifikan terhadap sikap sosial dan hasil belajar IPA pada siswa kelas IV Sekolah Dasar Di Gugus 2 Selong Lombok Timur, sehingga peneliti lain hendaknya mengembangkan model pembelajaran berbasis masalah di berbagai tempat guna untuk meningkatkan kulitas pembelajaran di sekolah.

\section{DAFTAR PUSTAKA}

Afif, H. Z. 2015. "Science Process Skills and Attitudes toward Science among Palestinian Secondary School Students" (halaman 13-24). World Journal of Education. Volume 5 tahun 2015. (Diakses 9 Agustus 2017).

Esme, C. 2016. "Elementary School Students' Attitude toward Science and Related
Variables" (halaman 35-52).

International Journal of

Environmental \& Science Education.

Volume 11 tahun 2016. (Diakses 10 Agustus 2017).

Gunamantha, I. M. 2010. "Pendidikan Untuk PembangunanBerkelanjutn:

Mengapa, Apa, Dan Bagaimana" (halaman 215-221). Jurnal pendidikan dan pengajaran Undiksha. Volume 3 tahun 2010. (Diakses 11 Agustus 2017).

Karin, D. K. 2015. "Knowledge, Attitudes and Behaviour regarding Waste Management in a Grammar and a Comprehensive School in England $\tilde{n}$ Results from a School Questionnaire" (halaman 58-71). Journal of Teacher Education for Sustainability. Volume 17 tahun 2015. (Diakses 11 Agustus 2017).

Marhaeni .2013. Landasan Dan Inovasi Pembelajaran. Singaraja: Universitas Pendidikan Ganesha.

Mariana, I. M. A., dan Praginda, W. 2009. Hakikat IPA dan Pendidikan IPA: Bandung: Pusat Pengembangan dan Pemberdayaan Pendidik dan Tenaga Kependidikan IPA.Primary Educational. 1(1):57-63.

Purnama, H. 2008. Ilmu Alamiah Dasar. Jakarta: Rineka Cipta.

Wikut, D. 2017. "Penerapan Problem Based Learning Sebagai Upaya Meningkatkan Sikap sosial Siswa Kelas V Dalam Pembelajaran Ipa Di Sekolah Dasar" (halaman 1-28). Jurnal pendidikan dan pengajaran. Volume 3 tahun 2017. (Diakses 11 Agustus 2017).

Zulkarnaen., dkk. 2017. "Pengaruh Model Pembelajaran Berbasis Masalah Dengan Pendekatan Kontekstual Terhadap Aktivitas Dan Hasil 
JUPE: Jurnal Pendidikan Mandala

http://ejournal.mandalanursa.org/index.php/JUPE/index
Vol. 4. No. 5 Desember 2019

p-ISSN: 2548-5555 e-ISSN:2656-6745

Belajar Ipa Biologi Siswa Kelas Vii Smp Negeri 1 Sibulue" (halaman 19). Jurnal Pendidikan dan Pengajaran, Volume 4 tahun 2017. (Diakses 11 Agustus 2017). 